\title{
The mango in French-speaking West Africa: varieties and varietal composition of the orchards
}

\author{
Jean-Yves ReY ${ }^{a *}$, Thierno Mamadou DiALlo ${ }^{b}$, Henri VANNIÈREa ${ }^{a}$, Christian DIDIER ${ }^{a}$, Sidiki KÉITA $^{c}$, Morodjan SANGARÉc
}

${ }^{\text {a }}$ Cirad, UPR Productions fruitières, TA 50/PS4, Bd de la Lironde, 34398 Montpellier Cedex 5, France

Jean-yves.rey@cirad.fr

b IER, URG, BP 30, Bamako, Mali

c Irag, CRA Bordo, BP 352

Kankan, Guinée

\section{The mango in French-speaking West Africa: varieties and varietal composition of the orchards.}

Abstract - Introduction. The mango tree is one of the most widespread fruit trees in West Africa. A history of its introduction into that area was recently published. To follow upon this document, the presented analysis was devoted to the principal varieties that are cultivated there today and to the impact of the historical and commercial factors on the varietal composition of the orchards. Some definitions. In precondition to an inventory of the varieties, certain terms making it possible to characterise them were specified (precocity, monoembryony and polyembryony) and some information on the origin of the Floridian varieties was provided. Principal varieties cultivated in West Africa. Four mango variety categories were distinguished: varieties of local or polyembryonic mangos (mangots and Number One), first monoembryonic varieties propagated by grafting (Amélie, Julie, Sabot, Djibelor and Cuisse Madame), and the Floridian varieties, also monoembryonic and propagated by grafting, introduced later and used either for export (Kent, Keitt, Palmer, Zill, Valencia, Smith, Irwin and Haden), or for the regional markets (Brooks, Davis-Haden, Miami Late, Springfels, Beverly, Eldon and Ruby). Each variety was described, like its farming characteristics and its outlets. The composition of the grafted mango tree orchards. This composition is influenced by the historical evolution and the purpose of the fruits that can be eaten, sold on the local, national or subregional market, exported toward the international market or processed in artisanal or industrial units. This orchard composition was specified for Guinea, Mali, Burkina Faso, Côte d'Ivoire, Senegal and Togo.

Francophone Africa / Mangifera indica / introduced varieties / agronomic characters / precocity / fruits / phenotypes

La mangue en Afrique de l'Ouest francophone : variétés et composition variétale des vergers.

Résumé - Introduction. Le manguier est l'un des arbres fruitiers les plus répandus en Afrique de l'Ouest. Un historique de son introduction dans la zone a été publié récemment. Pour faire suite à ce document, l'analyse présentée a été consacrée aux principales variétés qui y sont cultivées aujourd'hui et à l'impact des facteurs historiques et commerciaux sur la composition variétale des vergers. Quelques définitions. En préalable à un inventaire des variétés, certains termes permettant de les caractériser ont été précisés (précocité, monoembryonie et polyembryonie) et quelques informations sur l'origine des variétés floridiennes ont été fournies. Les principales variétés cultivées en Afrique de l'Ouest. Quatre catégories ont été distinguées : les variétés de mangues locales ou polyembryonnées (mangots, mangue du Cameroun), les premières variétés monoembryonnées propagées par greffage (Amélie, Julie, Sabot, Djibelor, Cuisse Madame), les variétés floridiennes, également monoembryonnées et propagées par greffage, introduites plus tardivement et utilisées soit pour l'exportation (Kent, Keitt, Palmer, Zill, Valencia, Smith, Irwin, Haden), soit pour les marchés régionaux (Brooks, Davis-Haden, Miami Late, Springfels, Beverly, Eldon, Ruby). Chaque variété a été décrite, de même ses caractéristiques culturales et ses débouchés. La composition des vergers de manguiers greffés. La composition des vergers greffés est influencée par l'évolution historique et la destination des fruits qui peuvent être autoconsommés, vendus sur le marché local, national ou sous-régional, exportés sur le marché international ou transformés dans des unités artisanales ou industrielles. Cette composition a été précisée pour la Guinée, le Mali, le Burkina-Faso, la Côte d'Ivoire, le Sénégal et le Togo.

Afrique francophone / Mangifera indica / variété introduite / caractère agronomique / précocité / fruits / phénotype 


\section{Introduction}

According to the already published history retracing the spread of the mango tree in West Africa [1], the first mango trees planted in this zone were the fibrous-fruited polyembryonic mangots. Introduced during the 19th Century, they experienced strong growth during the second half of this century. The grafted monoembryonic varieties were established after 1890. Initially, only Amélie, and to a much lesser degree Divine and Julie, were significantly widespread. It was only from 1960, and again after 1980 that the Floridian varieties, introduced in 1949 at the Foulaya station, near Kindia in Guinea, experienced strong growth in West Africa.

Study of the development of intercontinental exports [1] showed that they had started at the end of the 1960s. Dominated from 1970 to 1990 by Mali, followed by Burkina Faso, they were later primarily driven by Côte d'Ivoire, which, with the development of sea shipments, experienced strong growth of its exports in the following decade. More recently, Senegal has also greatly increased its shipments.

During these periods, the Amélie variety formed the bulk of the first exports. Subsequently, it was largely replaced by the Floridian varieties (Kent, Keitt, Palmer, Valencia, etc.) [1].

The study presented is a continuation of the history mentioned in brief above. It concentrated on the main mango tree varieties cultivated in West Africa and on the impact of historical and commercial factors on the varietal composition of the orchards. Some concepts such as precocity, mono and polyembryony, and some information on the origin of the Floridian varieties, which along with Amélie form nearly all of West Africa's grafted orchard stock, were specified in the foreword to aid overall comprehension.

\section{Some definitions}

\subsection{Precocity}

The term "precocious", applied to fruit species, may have several meanings. It can qualify either a tree which bears fruit soon after being planted, or a variety (or species) capable of producing its fruits before the others in the season. In our presentation, we used the terms "precocious, precocity" (and their opposites "late, lateness") in this latter sense, reserving the expression "quick-fruiting" for trees bearing fruit young.

In the dry savannah zones, where export mangos are produced, there is a gradient of fruit bearing periods. The most precocious zones are situated in southern Korhogo (Dikodougou, Tafiré) in Côte d'Ivoire, and the latest are located further north and, to a lesser extent, to the west. So, the mangos of Senegal's Niayes or those of the most northern zones (Senegal's lowland valleys) are the latest. This change is primarily due to the extended cold period.

Furthermore, the harvesting of the first fruits must not be confused with the peak of production of the variety within the same zone. In the cities, trees planted in residential areas are subject to numerous attacks (entanglement with cables, debarking, machete damage, spiking), and are regularly subjected to smoke during the preparation of meals on wood fires. Smoking is a technique used in Asia to trigger tree flowering [2]. This could explain why old mango trees planted in urban areas bear more fruits out of season than young trees in rural orchards, and why small Amélie crops appear in Bamako from February, although the production peak for this variety is in April-May. For greater consistency in our document henceforth the production date of the variety will be defined according to the harvest peak.

Within a given zone, the production period of a variety depends on the particular conditions of the plot: microclimate, soil, tree history, etc. At the fruit research station of Korhogo [National Agronomy Research Centre (CNRA)] in northern Côte d'Ivoire, extending over 40 ha, yields of plots of the same variety may be nearly a month apart.

\subsection{Monoembryony and polyembryony}

Zygotic (sexual) embryos come from fertilisation: the female gamete, or oosphere, 
with $\mathrm{n}$ chromosomes, is fertilised by the male gamete, or sperm nucleus (n chromosomes). After this fertilisation process, the egg or zygote has $2 \times \mathrm{n}$ chromosomes. In heterozygous plants (non-fixed), the embryo created from genetic recombinations during the process of meiosis and fertilisation has a different genome to that of the mother, and its brothers and sisters.

However, apogamous embryos originate from diploid somatic cells (with 2 n chromosomes), most often originating from the ovum nucellus, hence they are known as "nucellus embryos". Since they are created from reproduction of a somatic cell which has not undergone any process of meiosis or fertilisation, these embryos have the same genetic potential as the mother plant. This mechanism provides seedlings and then trees identical to the mother plant, even in heterozygous species. With the exception of rare cases of embryo polyploidy or extraordinary properties in the mother, plants from somatic embryo seedlings are therefore genetically equivalent to those obtained by vegetative propagation. The phenotypes are however distinguished by a long juvenile phase, shortened by the vegetative propagation of adult organs.

In the mango tree, seeds of monoembryonic varieties contain only one zygotic embryo. The stones of polyembronic varieties have one (or no) zygotic embryo, and one or more somatic embryos. In free pollination, the percentage of stones containing zygote embryos is $20 \%$ for Turpentine and $22 \%$ for variety $13-1$, whereas it falls to $13 \%$ for Turpentine if these two cultivars are placed in isolation cages [3]. Some varieties, such as Carabao, Pico and Cambodiana, appear to only have nucellus embryos [4].

Generally, polyembryonic varieties are more productive. The persistence of nucellus embryos promotes fruit setting [5]. Conversely, in monoembryonic varieties, it is rare for parthenocarpic embryonic varieties to develop after termination of the zygotic embryo. The tougher the environmental conditions during the flowering period, the greater the advantage of the polyembryonic varieties over the monoembryonic varieties. This is the case in dry savannah zones, where the low humidity of the harmattan season does not always favour good pollination.

\subsection{The genetic origin of the Floridian varieties}

The mango trees believed to have originated in the Indo-Burman region [1] appear to have spread in two directions: to Malaysia and South-East Asia, producing polyembryonic varieties, and towards the Gulf of Bengal and India, producing monoembryonic varieties [4]. In fact, the majority of Indian mangos are monoembryonic. The rare polyembryonic varieties present on the West coast of India appear to have been introduced to Goa by the Portuguese from their Asian possessions, Macao or Timor [4].

On the American continent, mango trees were introduced from their two primary origins. In the 18th Century, the Asiatic polyembryonic varieties were planted in Central America (Mexico and Panama), and then in the Caribbean by the Spanish who had reached Asia by the Pacific Ocean after rounding America via the Strait of Magellan [6]. The names of the Mexican varieties such as Manila or Philipino are a reminder of their origin. Other mango trees appear to have come from the east, introduced by way of Africa or the Indian Ocean islands initially. The Portuguese appear to have planted the first mango trees in Bahia, Brazil, but "not before 1700" according to Popenoe [6]. In 1782, a ship containing mango plants from the Isle of France, now Mauritius, bound for Hispaniola (Haiti, Santo-Domingo) was captured by British pirates and sent to Jamaica, where the trees were planted and prospered. Thirty-two years later, the mango tree had become a very common plant there [6].

In the United States, the first introduction appears to have been made near Miami in 1833, with plants from Mexico. But then, with the progress of transportation, imports of various origins multiplied [6]. From 1889, monoembryonic Indian grafted plants were systematically introduced in Florida by the United States Department of Agriculture (USDA), including the Mulgoba variety, a seed from which would give rise to Haden $[6,7]$. Many Floridian cultivars, such as Eldon, Smith, Lippens, Tommy Atkins, Zill, 
Glenn, Springfels and Valencia are descended from Haden. Keitt apparently originated directly from Mulgoba, while the Irwin variety apparently originated from Lippens, and Spirit of 76 from Zill seedlings. Edwards was apparently a hybrid of Haden and Carabao [7].

After Mulgoba, Sandersha [6, 7] was the second Indian monoembryonic variety used as a progenitor in Florida. Brooks and Anderson originated from Sandersha seedlings, whereas Kent apparently originated from Brooks and Fascell was a hybrid of Haden and Brooks [7]. The name Saigon was attributed to a group of trees originating from a batch of seeds that D. Fairchild had sent to the USDA from Saigon, now Ho Chi Minh City, Vietnam. Cambodiana originated from selection made within this group of highly heterogeneous trees in terms of size and shape, and the Florigon variety apparently originated from a Saigon seedling [6, 7]. The parentage of Palmer and Ruby is unknown [7].

So, most of the Floridian varieties that we have more especially studied are apparently descended from two Indian monoembryonic varieties.

\section{The main varieties cultivated in West Africa}

Although the introduction of mangos to West Africa is recent, the inhabitants distinguish the "local mangos" or mangots, which are polyembryonic, seed reproducing, mainly fibrous, from the "imported mangos", which are monoembryonic, and reproduce by grafting. For practical reasons, we will adopt this distinction by classifying West African mango varieties into three main groups: polyembryonic varieties, Floridian varieties and other varieties, primarily represented by Amélie.

\subsection{Local or polyembryonic mangos}

\subsubsection{The Nunkourouni, or Tête de chat, Mangot}

The fibrous, polyembryonic Nunkourouni mangot (figure 1) is widespread throughout
West Africa and Central Africa. In each site it bears a different name which may be related to the origin of its introduction (Sierra Leone in Senegal, German mangot in certain areas of Cameroon), to the zone where it is cultivated (N'gaoundéré mango, in Adamaoua, Cameroon) or to the shape of the fruit. In mandinga languages, the shape of the fruit is often likened to parts of the face (mouth, nose, etc.). So this mango is known as Nez court (Short noze) or Tête de chat (Cat's head) (Nunkourouni or Diakuma Koun or Mankoron Ba). It is also called Greffeul in Senegal.

The tree is vigorous, with dark green foliage. The leaves are long with undulating edges, and the inflorescence is red coloured. Adult trees are highly productive. Production is very precocious in the season, which makes them the first mangos on the market.

The fruit is flattened laterally, with a rounded shape and a ventral shoulder which extending down quite a long way. There are many local types and the fruit shape varies according to the production zones. Their weight varies from (150 to 300) g. The skin is red, yellow or green when ripe. The bright orange pulp, rich in volatile compounds [8], has a very pleasant taste. The very many short fibres which stick to the stone for a long time impaired its industrial use. However modern processes such as the "flash-détente" technique enable the pulp to be used without the inconvenience of the fibres.

The number of trees producing Nunkourouni mangots in each country is difficult to evaluate, since most surveys on mango trees do not count trees from seedlings deemed of low economic benefit. Orchards of purely this variety are rare today, but it is present in all living spaces: squares, yards, arches, railway stations, roadsides and street sides, isolated or in groves in the fields. As it is used as a rootstock, it is possible to observe isolated individuals in orchards when the graft fails or if a reject has taken over the graft. If new growth from the rootstock has not been eliminated, the branches of the grafted variety cohabit with those of the rootstock.

In a city like Conakry (Guinea), there is at least one mango tree of this variety per 

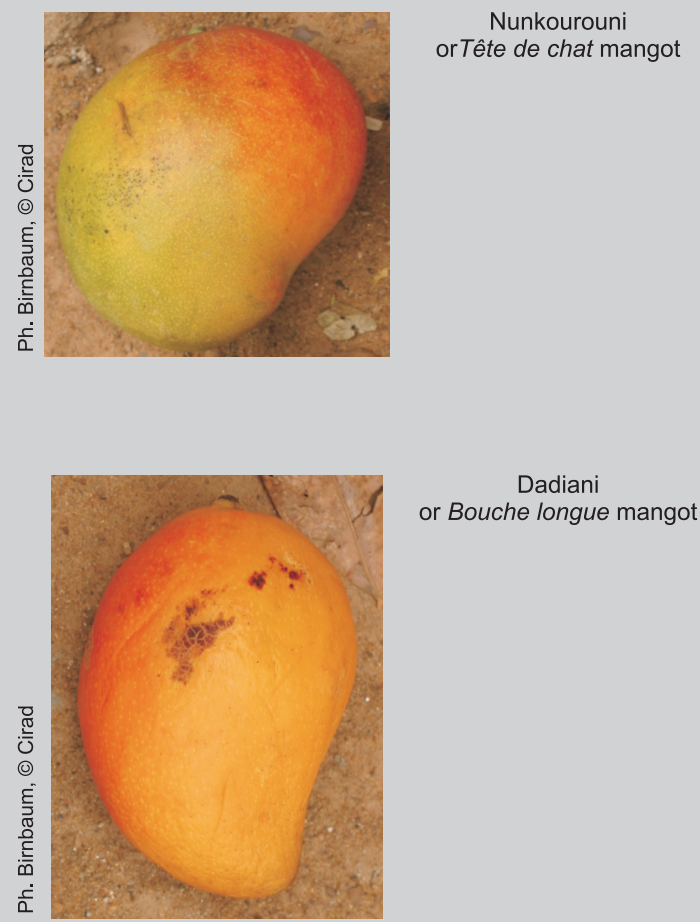

Sabot variety
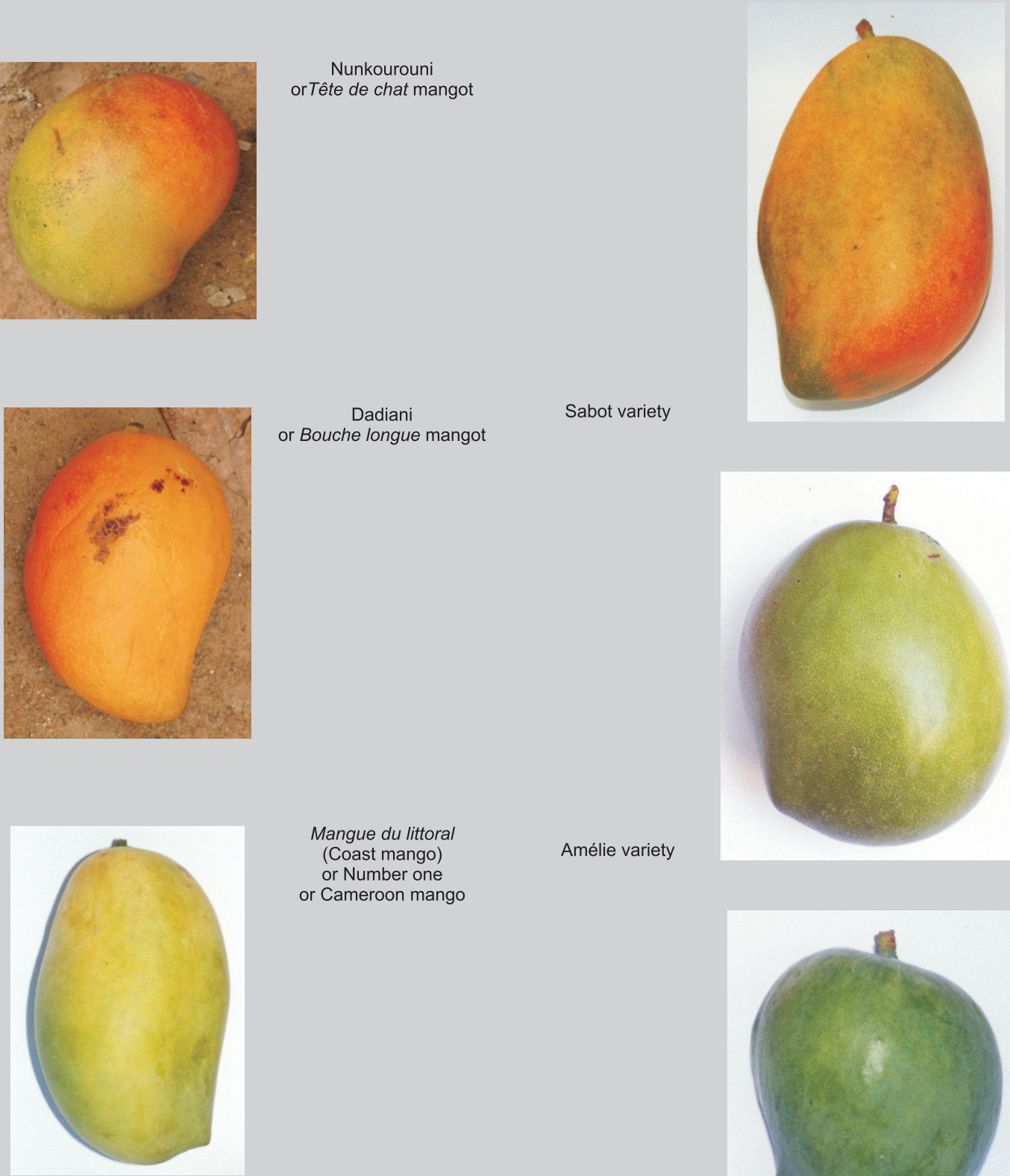

Mangue du littoral (Coast mango)

or Cameroon mango

Amélie variety

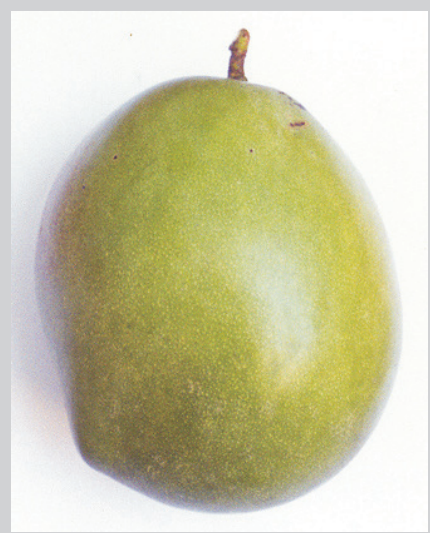

Polyembryonic seed propagated varieties

$10 \mathrm{~cm}$
Djibelor variety or Pêche (Peach) variety

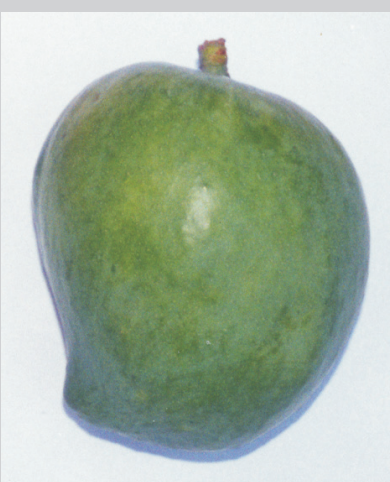

Monoembryonic graft propagated varieties

\section{Figure 1.}

Some polyembryonic mango varieties consumed locally, and presentation of some monoembryonic varieties among the first to be propagated in West Africa by grafting (a color version of this figure is available at www.edpsciences.org/fruits). 
house. Between Conakry and Mamou, around $300 \mathrm{~km}$ apart, these mango trees line the road over half of its distance. The Nunkourouni mango tree is present in all the cities of Upper Guinea, where it constitutes the shade tree for public avenues and squares. This variety is present not only in all West African countries, but also in the wet zones near the ocean and in the dry savannahs.

Production of Nunkourouni mangots is as difficult to evaluate as the number of its trees, since the fruit is for self-consumption or sold in local markets. Children harvest mangots in treetops by climbing into the branches or bringing them down by throwing stones. Evaluations gave average yields of (150 to 200) kg of fruit per tree per year. Production could be evaluated as at least $50000 \mathrm{t}$ per country, but much higher for countries such as Guinea or Mali.

\subsubsection{The Dadiani, or Bouche longue, mangot}

Just like the Nunkourouni mangot tree, the polyembryonic variety which produces the Dadiani mangot (figure 1) is known under different names. The tree has a less erect shape than the previous mangos. The inflorescence is whitish yellow. The fruit is small, (150 to 250$) \mathrm{g}$. Its skin is light green to yellow with pink to red mottling when ripe. The ventral shoulder is short and the apex long, hence the names Bouche longue (Long Mouth) or Nez long (Long nose) (Dadiani, Nundiani). In the publications of Ollé et al. $[9,10]$, it is known by the name of Mbengué, the city where it was harvested for these trials. The apex part of the fruit is straight or slightly curved, hence the name 'Sabre' which it is given in certain collections. The flesh is yellow to light orange. The fruits are sensitive to anthracnose. There are many fibres; the pulp is less flavoured and more delicate than that of Nunkourouni. The productivity of adult trees is very good. Production is precocious in the season, coinciding with that of Nunkourouni. Although widely represented, this mango is however less widespread than the previous one.

For these two mangots, the delicacy of the pulp, the small size of the cheeks and the difficulties of agri-business use of the fibrous pulp using conventional techniques meant that these fruits were largely reserved for self-consumption and the local markets. Their abundance in the production season enables broad sections of the population to have their fill of them. In Guinea, the inhabitants prefer these varieties to any others, and the precocious grafted varieties find few takers.

\subsubsection{Other mangots and local varieties}

Besides the Nunkourouni and Dadiani mangots, there are other fibrous mangots such as Mangotine (Fumani), which has small, very sweet smelling fruits of (80 to 100) g, and Mangot vert (Green mangot), introduced from the West Indies at the Foulaya station (Guinea). Some other varieties may be abundant on a regional or national scale, such as the small known as the Séwal in Senegal.

\subsubsection{The Cameroon mango}

The Cameroon mango (figure 1) requires special presentation. Introduced initially to the Douala region (Cameroon), this polyembryonic variety was propagated by seeds along the coast before being widely distributed to the interior of the country, in Yaoundé, the forest zone, then to the north and neighbouring countries. It is known under various names - Mangue du littoral (Coast mango), in the French-speaking part, and Number One, in the English speaking zone are the best known. Outside of Cameroon, it is called the Cameroon mango or Améliorée du Cameroun (Cameroon refined) (this latter term originally encompassed five clones selected by de Laroussilhe, who had named them Ifac 1 to Ifac 5).

In several West African countries, this variety was propagated primarily by grafting. Consumed locally, it has never had the relative importance that it has in Central Africa.

The tree may grow strongly under favourable conditions. The leaves are big, with undulating edges. The fruits are small, with yellow or green skin when ripe, with a delicate non-fibrous pulp, highly sensitive to jelly seed around the stone. Depending on the fruits, the pulp colour varies between bright orange and whitish, through various 
shades of yellow. The taste is fairly understated, pleasant smelling and slightly acidic.

The tree and fruit are reminiscent of some South-East Asian varieties. Its main benefit is bearing abundant fruit in the wet zones. But the characteristics of the fruit (green skin, pulp delicacy, small size, etc.) impair long-distance sale.

\subsection{The first monoembryonic varieties propagated by grafting}

\subsubsection{Amélie}

The Amélie variety (figure 1), whose origins are not really known, was introduced from the West Indies at the catholic mission of Kita. Is it the same variety as the ReineAmélie mentioned by Sébire in the Thiès collection [9]? It is currently widespread in all the dry savannah zones north of $9^{\circ}$ latitude $\mathrm{N}$, although it is sometimes found mixed in orchards situated further south, in Togo for instance. This geographic distribution is related to its sensitivity to flower and fruit mycoses (oidium, anthracnose). Its relative importance in the savannah earned it the name of "greffée" (grafted) in many places, where it was it was for a long time the only grafted variety. It is also known as Gouverneur, particularly in Burkina-Faso.

The tree has a characteristic shape, very different to that of the Floridian varieties. Of modest size, it has dense leafing in a ball shape. Its highly ramified branches bear small, flat light-green leaves with regular edges.

The fruit has a green or yellow skin when ripe, which in the lateritic soils may take on a beautiful red coloration on the part exposed to the sun. The flesh is a beautiful bright orange. The sugar and acidity levels vary according to the farming conditions, but are generally below those of Floridian cultivars [10]. The taste and smell are easily recognisable. According to Ollé et al.[9], the aromas of Amélie are special, "as they are practically lacking in car-3-ene, with (Z)and (E)-ocimene as the primary monoterpenes. The latter two volatile compounds have a hot, grassy and floral odour, while the odour of car-3-ene is mild, reminiscent of refined limonene".
These aromas were also apparently found in puree and ripe or green Indian Alphonso mangos or in those of the Jaffna cultivar cultivated in northern Sri Lanka [8]. In West Africa, we only know a single cultivar which has the same taste as Amélie. This is a highly coloured red skinned variety in a collection at CNRA, Korhogo, but which practically is not distributed.

Amélie is the most precocious of the commercial varieties. Cold storage of green fruit is satisfactory in spite of a certain sensitivity to flaking, which causes fairly rapid degradation of ripe fruits. The lack of red coloration on the skin of this variety and its relatively short shelf life encourage European importers to favour other cultivars, but its precocity means it can be exported until the red varieties arrive.

The production of Amélie, which can reach several hundred kilos on certain trees, is very low on average, due in particular to a poor fertilisation rate (table I). In northern Côte d'Ivoire, the average export fruit yields of this variety fluctuate between ( 1 and 2 ) $\mathrm{t} \cdot \mathrm{ha}^{-1}$.

\subsubsection{Julie and Sabot}

The West African Julie ${ }^{1}$ variety is different to that of the French West Indies, but it is close to the Sabot variety (figure 1). The shape of the tree is similar to the Amélie, but the leaves are undulated. The fruit is flat, square or oval-shaped with Julie, and clog shaped in Sabot. The skin colour varies from green to brown when ripe, with sometimes red spots. The very delicate flesh, dark yellow to orange in colour, has a highly pronounced musk taste prized by local consumers, who have given Julie the name Muscat. The fruit is practically untransportable due to its ripening speed and the delicacy of its pulp. Its distribution area is the same as that of Amélie, but apart from a few specimens kept by planters for personal

1 There is a Julie Kasowa present in the Irad collections (Institute of Agricultural Research for Development) in Cameroon, which is fairly widespread in the northern provinces of this country under the name Julie, but which is different from the mangos of the West African Julie variety. 
Table I.

Breakdown of female flowers and fruit bearing rates of three mango tree varieties at the Lataha station, Korhogo, northern Côte d'Ivoire (according to Briot [11]).

\begin{tabular}{lccc} 
Variety & $\begin{array}{c}\% \text { of female flowers } \\
\text { in apex position }\end{array}$ & $\begin{array}{c}\text { Average } \% \\
\text { of female flowers }\end{array}$ & $\begin{array}{c}\text { Fruit bearing rate } \\
\text { per panicle }\end{array}$ \\
\hline Amélie & $22.7( \pm 7.9)$ & $11.1( \pm 4.1)$ & 10 \\
Keitt & $65.5( \pm 18.0)$ & $30.1( \pm 8.9)$ & 31 \\
Kent & $32.5( \pm 8.9)$ & $20.5( \pm 6.0)$ & 25
\end{tabular}

consumption, these varieties are being abandoned.

\subsubsection{Djibelor}

In Casamance, in southern Senegal, the Djibelor mango, also known as the Pêche (peach) mango (figure 1) is an excellent fibre-free fruit. It is close to an Indian variety known as Paheri (aka - Peter Passand, Alphonse Paheri, Païri).

\subsubsection{Cuisse Madame}

Cuisse Madame was part of an orchard set up near Siguiri, in Upper Guinea, in 1931. It produces a large green-skinned fruit. Its spread is limited to Upper Guinea.

\subsection{The Floridian varieties used for export}

Since the monoembryonic Floridian varieties are widespread throughout the world, we undertook to describe their characteristics in the special conditions of West Africa.

\subsubsection{Kent}

The Kent variety (figure 2), Floridian in origin, was introduced at the Foulaya station in Guinea by Py in 1949. For around ten years, it has replaced the Amélie variety as the main West African export variety. Some fruit characteristics are heavily influenced by the soil types. At the Lataha CNRA station, near Korhogo (Côte d'Ivoire), which has a surface area of 40 ha, some plots can bear fruit nearly a month after the others. The fruits are precocious, firm and coloured on the lateritic hillsides, while they can be dark green, late and affected by physiological disorders on wet clay lowland soils.

The traditions of the Senoufos, the main ethnic group of northern Côte d'Ivoire, aimed to retain a balance between the annual crops (cotton and food producing) and perennial crops (mangos, cashew nuts and forest species). The first mango orchards were often relegated to the lateritic gravel hills, unsuitable for annual crops, but capable of producing precocious and magnificent fruits. This was one of the factors favouring the growth of exports from Côte d'Ivoire.

Kent bears fruit between 10 April and 20 May in the south of the export zone (Korhogo, Ferké in Côte d'Ivoire), in May in Sikasso (Mali) and in West Burkina-Faso, from 15 May around Kankan (Guinea), from May to July in Bamako (Mali) and from July to September in Niayes (Senegal). Some orchards around Korhogo can be fully harvested in mid-April.

The Kent variety is characterised by a relatively low pulp water content, which could explain its good shelf life (table II). The fruit ripens very gradually. The dry soluble extract of Kent mangos ready for consumption is high, and may reach $22^{\circ}$ Brix in some fruits, whereas acidity, lower when harvested than in the other varieties mentioned, is higher after ripening (table III).

Analyses of mangos from Northern Côte d'Ivoire conducted by Collin and Dalnic confirmed these results [12]. On the other hand, the analyses conducted by Ramata Diallo on ripe fruits from Maritime Guinea revealed dry soluble extracts and acidity levels below those of Korhogo for Kent and Keitt (table IV). These analyses conducted in July, i.e., 1.5 months after the start of the 


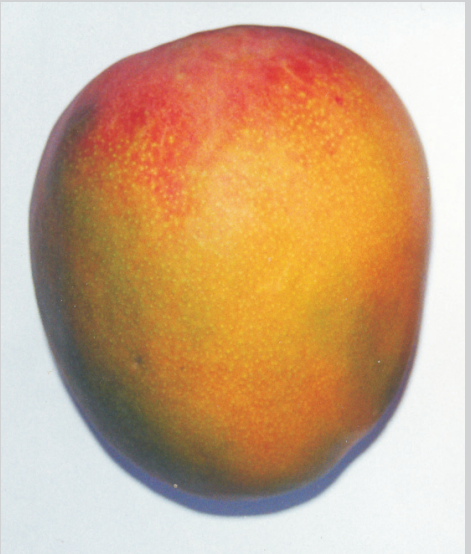

Kent variety

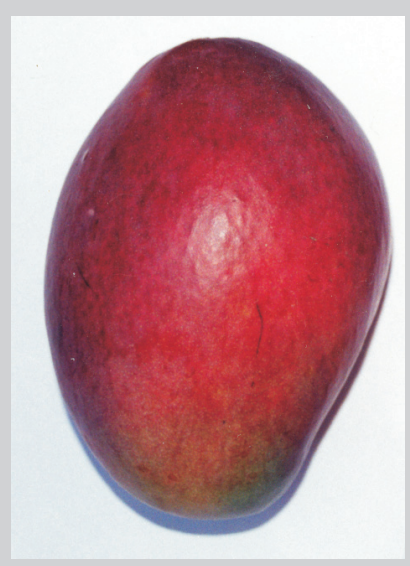

Palmer variety

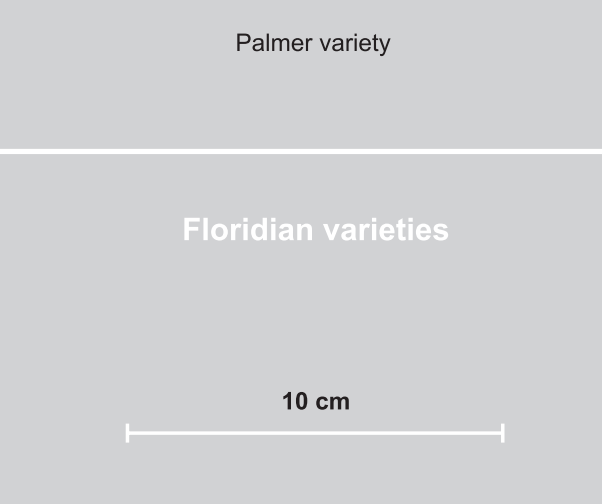

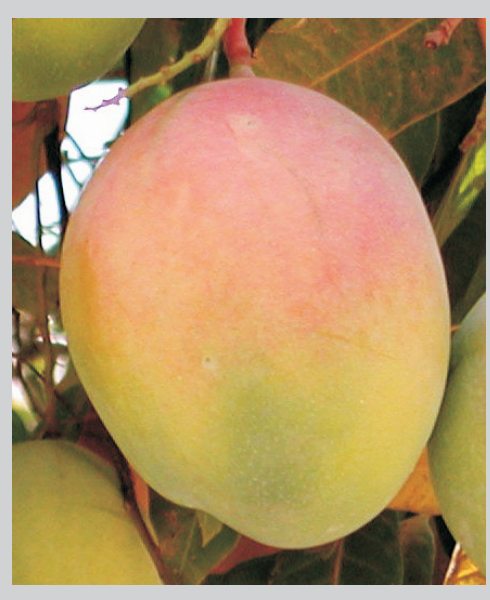

Keitt variety

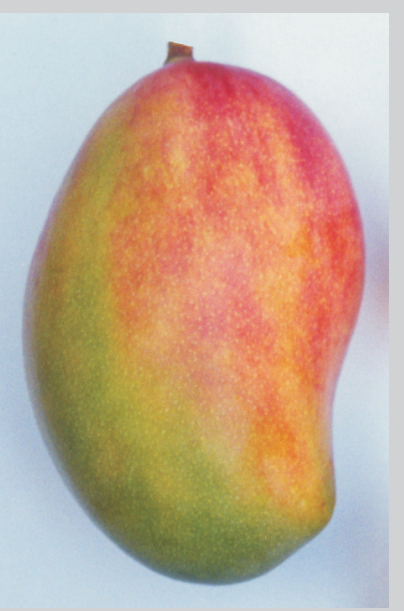

Valencia variety

Monoembryonic varieties used for export

\section{Figure 2.}

Presentation of Floridian monoembryonic varieties produced in West Africa and used either for export, or for the national or regional markets. (A color version of this figure is available at www.edpsciences.org/fruits.) 
Table II.

Skin and pulp dry matter of mangos from northern Côte d'Ivoire during the 1989 season (according to Collin and Dalnic [12]).

$\begin{array}{lcc}\text { Variety } & \begin{array}{c}\text { Pulp dry matter } \\ (\%)\end{array} & \begin{array}{c}\text { Skin dry matter } \\ (\%)\end{array} \\ \text { Amélie } & 14.37 & 22.15 \\ \text { Keitt } & 17.75 & 23.68 \\ \text { Kent } & 20.47 & 25.03 \\ \text { Mangot } & 18.38 & 23.51 \\ \text { Palmer } & 16.92 & 19.85 \\ \text { Ruby } & 20.15 & 27.24\end{array}$

rainy season, confirmed that Kent has the highest soluble dry extracts of the varieties analysed. Certain fruits (Kent and Keitt) were affected with physiological disorders.

The size of the Kent fruits, which primarily come in sizes 7 to 10 (number of fruits per $4 \mathrm{~kg}$ box), completely satisfies the demand of the European market, and in particular the French market.

When the fruits from the dry savannah ripen, the green colour of the skin disappears largely, giving way to a beautiful yellow. Then the ripe fruits are red and yellow or red, green and yellow. They are much more attractive when ripe than at their harvesting stage.
So the Kent variety combines many commercial qualities, which explains its success with European importers: good transport resistance, high conservation life of cold stored ripe fruit, high soluble dry extract, beautiful coloration of fruits produced in appropriate conditions, decent sizes.

\subsubsection{Keitt}

The Keitt variety (figure 2) was introduced, like Kent, by Py at Foulaya in 1949. It is the latest of the export varieties. Although some orchards produce fruit from mid-April near Korhogo, its harvest period extends from the end of April to the start of June in northern Côte d'Ivoire. In Sikasso (Mali) and in West Burkina-Faso (Orodara, Banfora), it produces fruit in May-June, and until July and sometimes August. In Bamako (Mali), the harvest extends from June to August and Senegal exports it until September-October.

The ripening time of the fruits is very long. It may be as much as 3 weeks at normal temperature for fruits which then develop normally. On the other hand, the ripe fruits have a shelf life shorter than Kent's. The soluble dry extract is relatively high, although the averages are slightly below Kent's (tables III, IV).

The harvested fruit's colour varies: green, light yellow with or without areas of a copper red. However, it changes little in ripening. Keitt's fruits, which are more coloured

Table III.

Soluble dry extract and acidity of three export mango varieties collected at the ripe stage for export in Korhogo, northern Côte d'Ivoire (according to Briot [11], Guépratte [13] and Moulio [14]).

\begin{tabular}{|c|c|c|c|c|}
\hline \multirow[t]{2}{*}{ Variety $^{1}$} & \multicolumn{2}{|c|}{ Analyses when harvested } & \multicolumn{2}{|c|}{ Analyses after ripening } \\
\hline & $\begin{array}{c}\text { Soluble dry extract } \\
\text { ('Brix) }\end{array}$ & $\begin{array}{c}\text { Acidity } \\
\text { (meq } 100 \mathrm{~g}^{-1} \text { of pulp) }\end{array}$ & $\begin{array}{l}\text { Soluble dry extract } \\
\text { ('Brix) }\end{array}$ & $\begin{array}{c}\text { Acidity } \\
\text { (mEq } 100 \mathrm{~g}^{-1} \text { of pulp) }\end{array}$ \\
\hline Amélie 89 d & $6.8 \pm 0.8$ & $26.8 \pm 3.8$ & $13.9 \pm 1.9$ & $9.0 \pm 3.4$ \\
\hline $\begin{array}{l}\text { Kent } 120 \mathrm{~d} \\
\text { (January flowering) }\end{array}$ & $9.4 \pm 1.5$ & $15.6 \pm 5.2$ & $19.9 \pm 2.2$ & $11.2 \pm 2.3$ \\
\hline $\begin{array}{l}\text { Kent } 120 \mathrm{~d} \\
\text { (February flowering) }\end{array}$ & $9.4 \pm 1.0$ & $18.8 \pm 4.8$ & $19.6 \pm 1.4$ & $10.6 \pm 2.1$ \\
\hline Keitt $132 \mathrm{~d}$ & $10.5 \pm 1.6$ & $19.4 \pm 4.3$ & $18.5 \pm 1.4$ & $7.9 \pm 1.8$ \\
\hline
\end{tabular}

1 The number of days corresponds to the arbitrarily chosen interval between flowering of the end flower of the panicle and the harvest. January or February were the flowering months of the inflorescences which bore fruits. 
than Kent's during conditioning, are less attractive when ripe.

The fruit size also varies according to the environmental conditions. On the gravel hillsides, the fruits are firm, coloured and of satisfactory size for export (6 to 10), although a significant proportion of production has to be rejected due to excessive size. On the other hand, on rich, wet soils, their skin remains green, or dark green ("black" in the vocabulary of the harvesters), and the size is too big for export (6 and under). Some fruits may exceed $1.5 \mathrm{~kg}$. Physiological disorders may also be observed, but less intense than with Kent.

The fruit-bearing peduncles are very long, and the branches are little ramified and supple. The fruits are thereby exposed to various hazards: friction against the ground or branches, insect damage, etc. The skin is much more sensitive to injuries than Kent's. In spite of good fertilisation, the average production of export fruits remains moderate, from ( 3 to 5 ) $t \cdot h a^{-1}$ in northern Côte d'Ivoire, which nonetheless makes it the most productive export fruit variety.

\subsubsection{Palmer}

The introduction of the Palmer variety (figure 2) in West Africa was the same as for the previous varieties. It is a medium late to late season variety, depending on the location. It produces somewhat after Kent: in May and early June in the south of the export zone, and from May to July in the North, in the Bamako region. The trees are productive. It is one of the most coloured varieties. With the exception of fruits embedded inside the foliage, over half of the fruit is coloured a dark purple. The rest is green when harvested, and becomes yellow when ripe.

The fruit size varies, but overall they are smaller than Kent's, with a high proportion of mangos from (300 to 450) g. This variety has low sensitivity to physiological disorders, and has good conservation properties. Its brix rate is higher than Amélie's: $17.2^{\circ} \mathrm{Brix}$ for Palmer as opposed to $13.1^{\circ}$ Brix for Amélie [10].

The Palmer variety is fairly difficult to handle for export. Its red coloration appears well before ripening of the fruit, and is mis-

\section{Table IV.}

Soluble dry extract and acidity of seven mango varieties after ripening, Maritime Guinea (according to Ramata Diallo, pers. comm.).

\begin{tabular}{lcc} 
Variety & $\begin{array}{c}\text { Soluble dry extract } \\
\left({ }^{\circ} \text { Brix }\right)\end{array}$ & $\begin{array}{c}\text { Acidity } \\
\text { (meq } 100 \mathrm{~g}^{-1} \text { of pulp) }\end{array}$ \\
\hline Kent & 14.6 & 6.2 \\
Keitt & 13.9 & 3.2 \\
Sabot & 13.7 & 7.4 \\
Lippens & 12.9 & 2.5 \\
Beverly & 12.5 & 10.8 \\
Brooks & 11.4 & 6.6 \\
Irwin & 12.1 & 4.9
\end{tabular}

leading for the harvesters. The abundant burning sap causes skin burns if precautions are not taken. Putting the fruit in long boxes is not easy: besides the small grades, it is impossible to arrange the fruits vertically, and, when they are placed flat, there is a risk of the box not reaching the minimum weight.

This variety is fairly well prized in the Northern European markets, especially in Belgium, where medium sizes, below those of the French market, are prized. In France, the Palmer mango is marketed in different ways according to the traders, but generally it does not sell as well as Kent.

\subsubsection{Zill}

After being highly prized at one time, the Zill variety is now little sought after in spite of its beautiful coloration when ripe. It suffers from major defects, especially its very fast development towards ripeness which leads to a very short shelf life. Often with low yield, it bears small fruits on the whole. Its advantage is reaching maturity a few days before Kent, enabling a few red fruits to be exported in the Amélie market period.

\subsubsection{Valencia}

The Valencia variety (figure 2), which was fairly well used for air exports, has been completely abandoned in Côte d'Ivoire with the development of ship exports, due to its poor transport resistance. It has, on the other hand, been rediscovered by Bamako air exporters, who value its beautiful coloration. The tree has a strong vegetal growth, 
but it does not have the production volume to match. In Bamako, the Valencia variety bears fruit before Kent.

\subsubsection{Smith}

The Smith variety, which bears fruit in the season or medium-late, has fairly good yields. It is highly sensitive to environmental conditions, both for the internal and external qualities. It often exhibits physiological problems, such as early overripeness of the apex part, or the development of roots in the pulp. The red coloration is important, but it varies from a striking vermilion to a dull wine red. The size may be satisfactory ( 7 to 9) or too big, with a majority of non-standard fruits. It is in the Yagoua zone, in northern Cameroon, that the most beautiful specimens of this variety can be found: abundant production, average size fruits, beautiful colour, firm flesh, etc. Since the Smith variety bears fruit at the same time as Kent in the present export zone, it is no longer of great benefit.

\subsubsection{Irwin}

With its beautiful coloration, the Irwin variety's shape varies according to the production zones. In the Kindia region, in Guinea, its fruit has an overall oval shape while in northern Côte d'Ivoire, it takes on an "S" shape with numerous deformations (bumps, finger-like protrusions, etc.). These anomalies are not due to cloning, since grafts taken from Kindia trees which bore good fruits reproduced the same anomalies at Korhogo. For a long time the main export variety from Maritime Guinea, the Irwin cultivar has been abandoned in favour of Keitt by Guinean exporters who believe that Irwin ripens too quickly for sea transport.

\subsubsection{Haden}

The Haden variety has yellow, green and bright red coloured fruits when ripe, which makes it the most beautiful export variety. Their flesh is sweet and attractive, in spite of the presence of small fibres. Depending on the environmental conditions, their size is medium to small. The yield of the tree is low to medium, depending on soil and water resources. This cultivar, which could have been widely distributed, is not widely spread, doubtless for historical reasons - it did not figure in the first collections - but also due to its modest productivity in difficult conditions and some physiological problems. The rare trees in production are difficult to manage because exporters do not have enough fruits at the same time to be able to make up complete pallets of the different sizes. Consequently, planters are not encouraged to plant more. Only a few air shipments are sent.

\subsection{The Floridian varieties used for the national and regional markets}

\subsubsection{Brooks}

The Brooks variety (figure 2) with its green, whitish or yellow skin when ripe, is often known as Retard because of its late production, from June to October in Côte d'Ivoire. The productivity of the tree is very high and regular from year to year. The fruits have firm flesh, are free from physiological disorders and prized by local consumers. On the other hand it is highly sensitive to fruit fly holes. The size is regular, with the majority of fruits between (350 and 450) g, which make good fruits portions. It is only lacking colour to be an excellent export variety!

\subsubsection{Davis-Haden}

The Davis-Haden cultivar is known as Kent Rouge in Mali, because of the beautiful skin coloration. The fruits are of an average weight varying from (500 to 1200) g, and they may exceed $1500 \mathrm{~g}$. With these fruits the flesh ripeness is highly irregular. The harvest, generally from July, is late and the fruits are highly sensitive to fly holes and fungal diseases, which leads to great losses. The size of the fruits and their sensitivity to diseases and pests make using this variety for intercontinental export difficult.

\subsubsection{Miami Late}

The Miami Late variety (figure 2) has a shape reminiscent of Kent's, but with a less developed area of red. In Mali, it is known as Souroukou Koun (Hyena's head). The lenticels are prominent and, when ripe, it does not have the striking colour of Kent. The 
fruits are of a regular size, generally weighing from (400 to 600) $\mathrm{g}$ although some fruits may be exceptionally big (over $1 \mathrm{~kg}$ ). The production period varies according to the environmental conditions, but overall it is medium-late to late. Production is abundant and regular. Along with Brooks, it is one of the most productive varieties, but also one of the most sensitive to fly holes. In wet zones, it is attacked by anthracnose. It does not withstand storage well.

\subsubsection{Springfels}

Springfels is, along with Davis-Haden, the cultivar that produces the biggest fruits, which has earned it the nickname name Papaye, by way of comparison with the local big-fruited papayas, rather than the Solo papaya variety. The skin is yellow and dull red when ripe. The fairly sweet pulp, which contains big longitudinal fibres, is prized locally. Production is medium-late and generally on a small scale.

\subsubsection{Beverly and Glazier}

These two varieties, originally introduced to Foulaya as with all the Floridian mangos, were positioned side by side in the collection established at the Guinean research station and their fruits are similar, which has led to subsequent confusions. While in Mali or in Guinea these cultivars are well distinguished, the same does not apply in Côte d'Ivoire, where the variety known as Beverly is actually Glazier, far inferior to the former. Glazier has red spots on the parts exposed to the sun, whereas Beverly is lighter, or even white under certain conditions. The fruits are medium to large, not very attractive when ripe, sensitive to fly holes and medium-late.

\subsubsection{Eldon}

The Eldon variety has a high yield in the season of yellow fruits with a somewhat muted copper coloration. The size is satisfactory, from (300 to 450) g, and the taste not very strong. This cultivar, with its medium-sized fruits, does not exhibit any quality in any area that could distinguish it and justify large plantations for the local market or export. Its main defect resides in the plentiful secre- tion of a burning sap, which causes damage on contact with the skin.

\subsubsection{Ruby}

Nicknamed Mademoiselle in northern Côte d'Ivoire, the Ruby variety is sought after by consumers who prize its acidic and fragrant taste. The skin is strongly red coloured, but the fruits are very small, and generally weigh less than $150 \mathrm{~g}$. These mangos are sound, and rarely suffer fly attacks. Although there is plenty on the trees, the harvested weight remains modest due to the small fruit size. Producers retain a few trees for self-consumption or local sale.

\section{The composition of the grafted mango tree orchards}

The composition of grafted mango tree orchards is influenced by historical development, and the purpose of the fruits, which may be for self-consumption, sale on the local, national or sub-regional markets, export to the international market or processing in artisanal or industrial units.

The historical development has four distinct distribution phases of the mango tree in West Africa: the expansion of seed mangots, the establishment of Amélie orchards, the distribution of coloured mangos from multilocal collections and the varietal concentration on Kent and Keitt, under the influence of the exporters. These stages often overlapped, so, in certain zones, the spread of the red varieties occurred alongside the expansion of Amélie.

\subsection{Guinea}

In Guinea, there are two big production regions. Maritime Guinea is the wettest West African mango export zone. It is primarily planted with varieties which were introduced at the Foulaya station (Kindia). Exports, which only represent a low percentage of production, have not had a significant impact on the varietal choices of the producers, especially since the choices of the exporters have evolved over recent years (from Irwin to Keitt). 
Upper Guinea has a hotter and drier climate than Maritime Guinea: it is reminiscent of the main production zones in neighbouring countries (Côte d'Ivoire, Mali, Burkina Faso). The first grafted mangos were above all Amélie, planted in the zone nearest to Mali (Siguiri). Mango trees then extended after the establishment in 1967 of a processing factory producing mango pulp. This factory worked more or less regularly until 1984 before being officially closed in 1985 . While it was active, the varietal choice focused on big-fruited, productive and late varieties to extend the factory's supply period. Of the varieties available in Guinea, Keitt and Miami Late best matched these criteria.

After the factory's closure, traders in the national market took over selling production. But since the mango market is saturated in the early season by the abundant mango production, the precocious or season varieties sell poorly. The demand is greater for the big, late and sweet fruits, which sell relatively well in the mining and forest regions. So Keitt and Miami Late continue to be the most planted varieties. The exporters' demand is very low in the zone, primarily coming from Côte d'Ivoire export agents who do not come to Guinea regularly every year. The Keitt variety is prized by the internal market, and not as an export variety; which explains why Kent production remains modest while Keitt's is high.

Upper Guinea is one of the production zones experiencing the biggest sale problems in West Africa. This is due in part to the remoteness of certain production zones from the big selling centres. In the other countries, it is relatively rare to see fruits rotting on the trees for lack of buyers.

\subsection{Mali}

In Mali, the various historical and economic influences have overlapped, making for a great diversity of situations. Around Bamako and in the Niger valley situated between the Guinean border and Koulikoro, the first grafted orchards had been established from Amélie mango trees. This variety is still now very clearly predominant within a radius of $70 \mathrm{~km}$ around the capital of Mali.
From the early 1970s, the Bamako elite developed prestige orchards. Located within a short distance of the city, these orchards were places of rest and relaxation. Their production was largely intended for consumption within family and friends, with sales covering all or some of the farming costs. The plantations constituted a land improvement enabling a "letter of allocation" to be drawn up, an important step towards obtaining a land deed. At this time planters aimed to have a staggered production to extend the harvest period as much as possible. Although it was good form to have a few big-fruited varieties, the taste of the mangos intended for self-consumption was more important than their appearance. However, to satisfy varied tastes and extend production, most of these orchards were genuine collections.

Later on, market requirements led to a reduction in the range of varieties, and today planters are keener to make their plantations profitable than 30 years ago. However, many family orchards are still planted by city dwellers whose main business is non-agricultural. Alongside the country folk's orchards, these city dwellers' orchards have made a great contribution to the fruit supply to the capital of Mali, and they have supplied a notinsignificant part of the export mangos. Subsequently, purely Kent and Keitt orchards were set up within a radius of under $30 \mathrm{~km}$ from the capital.

Around Sikasso, the composition of certain orchards also bears witness to the three plantation phases. The Floridian mango orchards coexist alongside Amélie orchards, but they comprise a much narrower range of varieties than in the Bamako region. These varieties are primarily those which were used for export when this was by air; however, the Brooks variety has been added to them. Furthermore, in southern Sikasso in particular, there are big Kent and Keitt orchards, fruit from which is intended for air or sea export.

The Bougouni-Yanfolila zone has been subject to many influences: the extension phase of Amélie mango trees, the establishment of a behaviour study orchard at Yanfolila, the proximity of Guinea and Côte d'Ivoire. The Guinean influence is reflected 
in the abundance of the Miami Late and Keitt varieties around Yanfolila, and between this city and the border. Near Côte d'Ivoire, big Kent and Keitt orchards were set up. These varieties are also found close to Bougouni. There are all types of orchards in Yanfolila.

According to a survey by the regional delegation of the Agency for the promotion of the agricultural industries (Aprofa Mali) in Sikasso, mentioned by the Agro-enterprise centre (CAE) [15] : "The evaluation study of the agricultural potential of the mango industry in the 3rd Region estimates the quantity available for export in the Sikasso region for the three main varieties at $48,181 \mathrm{t}$, of which 22,233 t for Amélie (46\%); 14,076 t for Kent (29.2\%); 11,872 t for Keitt (24.6\%). Assuming that only $30 \%$ can be used for export, taking into account the export standards and the degree of enclavement of the production region, Mali's export potential for the 3rd Region may be estimated at 14,454 t" $\mathrm{t}^{\prime 2}$. Mangos not exported from the 3rd Region are shipped to Bamako, to the northern cities (Ségou, Mopti, Gao) or to the neighbouring countries (Senegal, Mauritania).

\subsection{Burkina Faso}

In Burkina Faso, the main mango tree orchards are situated in the South-West of the country, in Banfora and Orodara in particular. The extension phase of the Amélie variety continued for much longer than in neighbouring countries. Orchards of varied Floridian cultivars were planted in great moderation. However, recent years have seen a great extension of Kent and Keitt with the plantation of new orchards or top grafting.

\subsection{Côte d'Ivoire}

In northern Côte d'Ivoire, the first orchards consisted of Amélie. Then orchards of var-

\footnotetext{
${ }^{2}$ In Mali, the 3 rd region contains the cities of Sikasso, Kadiolo, Bougouni, Yanfolila and Koutiala. It is bordered to the south by Côte d'Ivoire, to the east by Burkina Faso and the west by Guinea (Mandiana).
}

ious Floridian varieties developed, and their fruit was used for air export from 1980 to 1992. The demand for Kent and Keitt, which grew alongside the growth in sea exports, was reflected in the establishment of new orchards comprising these two varieties exclusively, and top grafting of the old orchards with Kent and Keitt. Besides the export varieties (Kent, Keitt, Amélie, Palmer and some Zill), only the Brooks trees and miscellaneous cultivars kept by the planters for family consumption are present. However, over $95 \%$ of grafted trees belong to the export varieties.

In the rainy zones, the fruit is not exported because of the plant health risks caused by humidity. The fruit intended for the local market is fairly diverse, but there are no big orchards as in the dry zones

\subsection{Senegal}

In Senegal, the first products of grafted varieties, Amélie and Divine, were intended to supply the urban markets, especially Dakar. The extension of the grafted mangos to Niayes was primarily influenced by the limited collections introduced through various organisations or private planters. However, in recent years, large areas have been planted with Kent and Keitt to satisfy exports or the national market. The trees are sprayed, at least in their juvenile phase, which leads to high production costs. The demand of the big urban market that the city of Dakar represents contributes to driving prices up. The production of Casamance, comprising various varieties, is little affected by exports.

\subsection{Togo}

In Togo, the public corporation Togofruits had planted a limited collection based on grafts from Mali. This orchard included the Amélie variety and various Floridian cultivars, which were distributed to the north of the country, but also to the wet zones. So mango tree orchards are found around Kpalimé. The most frequent varieties are those originating from the Bamako variety trial (Zill, Irwin, Smith, and Amélie), to 
which a few other should be added, such as Eldon or Springfels. The quantities processed or exported are low, and the vast majority of production is intended for the national or regional market.

In the other countries, production is primarily oriented to the national market.

\section{References}

[1] Rey J.Y., Diallo T.M., Vannière H., Didier C., Kéita S., Sangaré M., The mango in Frenchspeaking West Africa, Historical synthesis, Fruits 61 (4) (2006) 281-289 (translation of article published in Fruits 59 (3) (2004) 121129).

[2] Singh L.B., The mango, Leonard Hill Books Limited, London, UK, 1960, 439 p.

[3] Degani C., Cohen M., Reuveni O., El-Batsri R., Gazit S., Frequency and characteristics of zygotic seedlings from polyembryonic mango cultivars, determined using isozymes as genetic markers, in Bruce Schaffer (Ed.), Fourth int. mango symp., ISHS, Acta Hortic., No. 341, Wageningen, Netherlands, 1993, pp. $78-85$.

[4] Mukherjee S.K., Introduction: botany and importance, in: Litz R.E. (Ed.), The mango: botany, production and uses, Cab Int., Oxon, UK, 1997, pp. 1-19.

[5] Nagasone H.Y., Paull R.E., Mango, in: Tropical fruits, Cab Int., Oxon, UK, 1998, pp. 208238.

[6] Popenoe W., Manual of tropical and subtropical fruits excluding the bananas, coconut, pineapple, citrus fruits, olive and fig, Hafner Press, Div. Macmillan Publ. Co., New York, USA, 1920.
[7] Anon., Mangos: guide to mangos in Florida, Campbell R.J. (Ed.), Fairchild Tropical Garden, Miami, USA, 1992.

[8] Sébire A., Les plantes utiles du Sénégal, J.B. Baillière et fils, Paris, France, 1899, pp. 79-80.

[9] Ollé D., Baumes R.L., Bayonove C.L., Lozano Y.F., Sznaper C., Brillouet J.M., Comparison of free and glycosidically linked volatile components from polyembryonnic et monoembryonnic mango (Mangifera indica L.) cultivars, J. Agric. Food Chem. 46 (3) (1998) 10941100 .

[10] Ollé D., Lozano Y.F., Brillouet J.M., Isolation and characterisation of soluble polysaccharides and insolubles cell wall material of the pulp from four mango (Mangifera indica L.) cultivars, J. Agric. Food Chem. 44 (1996) 2658-2662.

[11] Briot E., Étude de la physiologie postrécolte de la mangue : projet de fin d'études, UTC Compiègne, France, 1999.

[12] Collin M.N., Dalnic R., Comparaison de mangues en provenance de Côte d'Ivoire, in: Journ. agrumes/mangues, Irfa, Inra, Montpellier, France, 1991.

[13] Guépratte M., Physiologie postrécolte de la mangue et conservation sous atmosphère modifiée, Mém. Éc. Sup. Agric. (ESA), Angers, 1998, 44 p.

[14] Bissardon F., Physiologie postrécolte de la mangue et conservation en froid de la mangue, Mém. ENSIA, Montpellier, France, 1999.

[15] Anon., Études pour la promotion des filières agro-industrielles. Vol. III. Analyse de l'état des filières des produits, Centre agro-entreprise (CAE), Étude Yiriwa Conseil, Bamako, Mali, février 2001. 


\section{El mango en África Occidental francófona: variedades y composición varietal de los huertos.}

Resumen - Introducción. El mango es uno de los árboles frutales más extendidos en África Occidental. Recientemente se publicó una reseña histórica de su introducción en la zona. Como continuación de dicho documento, este análisis está dedicado a las principales variedades que se cultivan actualmente y al impacto de los factores históricos y comerciales en la composición varietal de los huertos frutales. Algunas definiciones. Antes de inventariar las variedades, se especifican algunos términos que permiten caracterizarlas (precocidad, monoembrionía y poliembrionía) y se proporciona información sobre el origen de las variedades floridanas. Las principales variedades cultivadas en África Occidental. Se han distinguido cuatro categorías: las variedades de mangos locales o poliembriónicas (mangots, mango de Camerún), las primeras variedades monoembriónicas multiplicadas por injerto (Amélie, Julie, Sabot, Djibelor, Cuisse Madame), las variedades floridanas, también monoembriónicas y multiplicadas por injerto, introducidas más tardíamente y utilizadas, bien para la exportación (Kent, Keitt, Palmer, Zill, Valencia, Smith, Irwin, Haden), bien para los mercados regionales (Brooks, Davis-Haden, Miami Late, Springfels, Beverly, Eldon, Ruby). Se describió cada variedad, así como sus características de cultivo y salidas de mercado. Composición de las plantaciones frutales de mangos injertados. La composición de los huertos de mangos injertados está influida por la evolución histórica y el destino de la fruta que puede servir para autoconsumo, venta en el mercado local, nacional o subregional, exportación al mercado internacional o para su transformación en unidades artesanales o industriales. Se detalló dicha composición en Guinea, Malí, Burkina-Faso, Costa de Marfil, Senegal y Togo.

Africa de habla francesa / Mangífera índica / variedades naturalizadas / características agronómicas / precocidad / frutas / fenotipos 